University of Nebraska - Lincoln

DigitalCommons@University of Nebraska - Lincoln

10-2007

\title{
New and Emended Descriptions of Gregarines from Flour Beetles (Tribolium spp. and Palorus subdepressus: Coleoptera, Tenebrionidae)
}

John J. Janovy Jr.

University of Nebraska - Lincoln, jjanovy1@unl.edu

Jillian Tikka Detwiler

Purdue University, jdetwile@purdue.edu

Samana Schwank

London School of Tropical Medicine, Samana.Schwank@Ishtm.ac.uk

Matthew G. Bolek

Oklahoma State University, bolek@okstate.edu

Alaine Knipes

University of Nebraska - Lincoln, lainey244@yahoo.com

See next page for additional authors

Follow this and additional works at: https://digitalcommons.unl.edu/bioscijanovy

Part of the Parasitology Commons

Janovy, John J. Jr.; Detwiler, Jillian Tikka; Schwank, Samana; Bolek, Matthew G.; Knipes, Alaine; and Langford, Gabriel J., "New and Emended Descriptions of Gregarines from Flour Beetles (Tribolium spp. and Palorus subdepressus: Coleoptera, Tenebrionidae)" (2007). John Janovy Publications. 58.

https://digitalcommons.unl.edu/bioscijanovy/58

This Article is brought to you for free and open access by the Papers in the Biological Sciences at DigitalCommons@University of Nebraska - Lincoln. It has been accepted for inclusion in John Janovy Publications by an authorized administrator of DigitalCommons@University of Nebraska - Lincoln. 


\section{Authors}

John J. Janovy Jr., Jillian Tikka Detwiler, Samana Schwank, Matthew G. Bolek, Alaine Knipes, and Gabriel J. Langford 


\title{
NEW AND EMENDED DESCRIPTIONS OF GREGARINES FROM FLOUR BEETLES (TRIBOLIUM SPP. AND PALORUS SUBDEPRESSUS: COLEOPTERA, TENEBRIONIDAE)
}

\author{
J. Janovy, Jr., J. Detwiler, S. Schwank, M. G. Bolek, A. K. Knipes, and G. J. Langford \\ School of Biological Sciences, University of Nebraska Lincoln, Lincoln, Nebraska 68588-0118. e-mail: jjanovy1@unl.edu
}

\begin{abstract}
The following new gregarine taxa are described from larvae of flour beetles (Coleoptera: Tenebrionidae): Awrygregarina billmani, n. gen., n. sp., from Tribolium brevicornis; Gregarina cloptoni, n. sp., from Tribolium freemani; Gregarina confusa, n. sp., from Tribolilum confusum; and Gregarina palori, n. sp., from Palorus subdepressus. In addition, the description of Gregarina minuta Ishii, 1914, from Tribolium castaneum, is emended. Scanning electron micrograph studies of these species' oocysts reveal differences in surface architecture. The Gregarina species have oocysts with longitudinal ridges, visible with SEM, whereas Awrygregarina billmani oocysts have fine circumferential striations; surface architecture is the main feature distinguishing the 2 gregarine genera. Although parasites from adult beetles are not included in the descriptions, adults of all host species can be infected experimentally using oocysts from the new taxa.
\end{abstract}

The so-called "flour beetles" include a number of stored product pests, particularly species of Tribolium and 2 species of Palorus (Coleoptera: Tenebrionidae). These insects have been used in ecological studies because of their ease of culture, as well as in research on parasite-induced host behaviors because of their role as intermediate hosts for helminths. Moreover, they have been studied in efforts to develop control methods (Shostak and Smyth, 1998; Yan et al., 1998; Pai and Yan, 2003; Arnaud et al., 2005). Flour beetles also represent interesting host-parasite systems in that all or most of the species, including both adults and larvae, are infected with gregarine parasites (Apicomplexa: Conoidasida: Gregarinasina: Eugregarinorida), and the presumed relationship among hosts provides a tractable laboratory model to explore experimentally the evolutionary constraints on host specificity. Such exploration requires, however, taxonomic description of the parasites involved.

With a group of related hosts and their congeneric or confamilial parasites, molecular methods, used in conjunction morphological characters, allow researchers to develop phylogenetic hypotheses and propose causal explanations such as cospeciation and host capture (Snyder and Tkach, 2001; LeónRègagnon and Brooks, 2003). Ideally, however, one should do experimental cross-infections to determine whether host-parasite associations are established by true host-parasite incompatibility or by ecological factors. With most systems involving parasites of vertebrate hosts, logistical burdens make this kind of experimental work very difficult, especially so, when the species are not routinely reared in captivity. With insects such as flour beetles, much of this logistical burden is lifted, especially because their gregarine infections are often as easily manipulated as their hosts (Clopton et al., 1991, 1992; Watwood et al., 1997).

In the case of Tribolium species, a number of gregarines have been described already, but the number of host species involved is low, and the descriptions themselves are sometimes not consistent with current practice (see Clopton, 1999), particularly with respect to oocyst morphology (cf. Ghose et al., 1986). The present study was intended to resolve some of the taxonomic problems surrounding the parasites of flour beetles and to bring the gregarine descriptions up to the standards established by

Received 5 October 2006; revised 7 March 2007; accepted 8 March 2007.
Clopton (1999) in anticipation of using both hosts and parasites in experimental parasite population and host-specificity studies.

\section{MATERIALS AND METHODS}

Insects were obtained from a variety of sources. Tribolium confusum and Tribolium castaneum were originally collected at the University of Nebraska Poultry Science Feed Mill, Lincoln, Nebraska, during the middle 1980s and have been maintained in culture since (Watwood et al., 1997). Tribolium madens, Tr. brevicornis, Tr. freemani, and Palorus subdepressus were obtained from the USDA Post-Harvest Grain Marketing Laboratory, Kansas State University, Manhattan, Kansas, in January 1999. Stock cultures were maintained in plastic jars or conical centrifuge tubes with finely perforated screw-cap lids in media consisting of $45 \%$ commercial whole-wheat flour, $45 \%$ wheat bran, $7 \%$ commercial wheat germ, and 3\% baker's yeast by volume. New cultures were started biweekly using 20 adults or mixtures of adults and larvae. Cultures were maintained in incubators set at $27 \mathrm{C}$ and provided with a pan of water inside to maintain humidity.

Hosts were dissected, and both fresh preparations and stained smears were made from guts that had been teased apart by the methods of Kula and Clopton (1999). Fresh preparations were made in Tenebrio sp. saline (Belton and Grundfest, 1962). Air-dried smears were fixed in alcohol-formalin-acetic acid, washed in $70 \%$ ethyl alcohol, stained in Semichon's acetocarmine, dehydrated, cleared in xylene, and mounted with Canada balsam (Sigma, St. Louis, Missouri) or Damar balsam (Spectrum, Gardena, California) (Pritchard and Kruse, 1982; Kula and Clopton, 1999). For measurements of living organisms, images were taken with a Nikon Coolpix 995 camera fitted with an Optem 25-7014 adapter (Optem International, Fairport, New York; www.optemintl com). Digital photograph numbers were recorded, and the actual total length of each specimen was measured using a calibrated ocular micrometer. Measurements were thus associated with each photograph and used to calibrate measurements taken with image analysis software.

Measurements were taken using Scion Image Beta 4.02 for Windows (Scion Corporation, Frederick, Maryland; www.scioncorp.com). For measurements, each photograph was converted to a 15.2-cm-wide (proportions constrained), 100 pixels/inch bitmap file, and the image was adjusted slightly for contrast if necessary, all using Adobe Photoshop 6.0 (Adobe, San Jose, California). Measurements taken were those of the extended gregarine set of Clopton (1999); they were copied to an Excel (Microsoft, Redmond, Washington) spreadsheet, then converted to micrometers using a calibration factor calculated from total length measured with the ocular micrometer and total length in image analysis software units. Some parasite dimensions, however, were simply calculated from those measurements taken instead of being independently measured (the Clopton, 1999, set contains several that allow this approach). The measurements included in the current descriptions are those in Table I. Correlations also were calculated between deutomerite length and nuclear distance posterior to septum. Shape terminology is that recommended by Clopton (2004a).

Gametocysts were harvested by isolating larvae overnight in the outside moat of Falcon 3010 plastic, organ tissue-culture dishes with a small piece of wet paper towel in the center well and the cover added. Gametocysts were then picked up with a fine camel hairbrush and trans- 
TABLE I. Morphological characters measured and abbreviations for these characters as used in this article.

\begin{tabular}{|c|c|}
\hline TL & Total length \\
\hline PL & Protomerite length \\
\hline PLP & Protomerite length posterior to widest point \\
\hline PWM & Maximum protomerite width \\
\hline PDSW & Width of the protomerite-deutomerite septum \\
\hline DWM & Maximum deutomerite width \\
\hline DLA & Length of deutomerite anterior to widest point \\
\hline DLP & Length of deutomerite posterior to widest point \\
\hline ND & Greatest nuclear dimension \\
\hline NDP & Distance of nucleus posterior to septum \\
\hline$r$ DL:NDP; $p / r=0 /$ & Correlation between deutomerite length and NDP \\
\hline PL/PLA & Protomerite length/length anterior to widest point ratio \\
\hline PL/PDSW & Protomerite length/septum width ratio \\
\hline PWM/PDSW & Protomerite maximum width/septum width ratio \\
\hline DL/DWE & Deutomerite length/width and mid-point ratio \\
\hline DL/DWM & Deutomerite length/maximum width ratio \\
\hline DLA/DL & Deutomerite length anterior to widest point/deutomerite length ratio \\
\hline DLA/DLP & Deutomerite length anterior to widest point/posterior to widest point ratio \\
\hline DWM/DWE & Deutomerite maximum width/width at midpoint ratio \\
\hline
\end{tabular}

ferred to $1 \%$ neutral buffered formalin to be washed for a few minutes before isolation for further observation or dehiscence. For gametocyst photography, cysts were placed in a hanging drop of 1:1 glycerin:tap water on a cover glass and allowed to dehisce. The cover glass was then placed on a slide, drop side down, for observation of dehiscence mechanism.

Oocysts were prepared for digital photography by allowing gametocysts to dehisce on $22 \times 22$-mm cover glasses resting on the center well of covered Falcon plastic organ culture dishes with water in the moat, then inverting the cover glasses on a slide and tacking the corners down with glue. With this technique, gametocysts could complete their early development in a high humidity atmosphere as demonstrated by Clopton and Janovy (1993), and oocysts could be photographed later under oil immersion in their "natural" state, i.e., in air, instead of being suspended in media such as glycerol or agar (Clopton, 1995; Clopton et al., 2004). Measurements were taken with ScionImage software as described above, but calibrations were done using a stage micrometer photograph. Because oocyst chains are twisted in such preparations, at least 50 oocyst lengths were measured, but the width and thickness measurements could only be taken on those cysts oriented in the proper direction. Thus, length, width, and thickness measurements are not necessarily from the same individual oocysts, but from the oocysts in chains resulting from dehiscence.

Oocysts were prepared for scanning electron microscopy in 2 ways First, oocyst chains were placed on $15-\mathrm{mm}$ round cover glasses coated with poly-L-lysine (Sigma-Aldrich, St. Louis, Missouri) according to package instructions. These cover glasses plus oocysts were then fixed

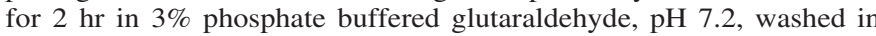
$0.1 \mathrm{M}$ phosphate-buffered sucrose solution, postfixed for $1 \mathrm{hr}$ in $1 \%$ osmium tetroxide in $0.1 \mathrm{M}$ phosphate buffer, washed with distilled water, dehydrated through an acetone series, critical point-dried using a Sorvall critical-point drying system (DuPont, Newtown, Connecticut), and sputter-coated with $200 \AA$ gold-palladium using a Technics (Osaka, Japan) Hummer II sputterer. In the second method, oocysts were simply sputter-coated without prior fixation. Scanning electron microscopy was performed at $15 \mathrm{kV}$ with a Hitachi (Tokyo, Japan) 3000N SEM. After comparison of electron micrographs taken of oocysts prepared by both methods, the latter was chosen for all the SEMs because no detectable differences in surface features could be observed in specimens prepared by the different methods.

Parasite hapantotypes and paratypes were deposited in the Harold W. Manter Laboratory of Parasitology (HWML), University of Nebraska State Museum (UNSM), Lincoln, Nebraska. Host symbiotypes were prepared according to instructions provided by Dr. Brett Ratcliffe, Curator of Entomology, UNSM, and deposited in that facility. Accession numbers for both hosts and parasites are provided in the taxonomic sections.

Drawings were made either with the aid of a camera lucida or by tracing video screen images on acetate sheets then tracing those images on to velum. Statistical analysis was performed with Excel and Statview. All measurements are reported in micrometers as the mean (range, standard deviation, $\mathrm{n}$ ).

\section{DESCRIPTION}

\section{Awrygregarina g. nov.}

Diagnosis: Eugregarinorida Léger, 1892, sensu Clopton (2000); Septatorina Lankester, 1885, sensu Clopton (2000), Gregarinicae Chakaravarty, 1960, sensu Clopton (2000), Gregarinidae Labbé, 1899, sensu Clopton (2000); with characters of Awrygregarina g. nov.: epimerite simple short cone; association precocious, cephalocaudal, biassociative; gamonts anisogamous, primite with protomerite conspicuously offset laterally ("awry"), mature satellite longer than primite and with attenuated posterior end; gametocysts spherical, dehiscing in chains through sporoducts; oocysts approximately spherical with fine circumferential striations.

\section{Taxonomic summary}

Type species: Awrygregarina billmani sp. nov.

Etymology: The generic name Awrygregarina is derived from the consistently offset protomerite of the mature primite, giving the ap- 


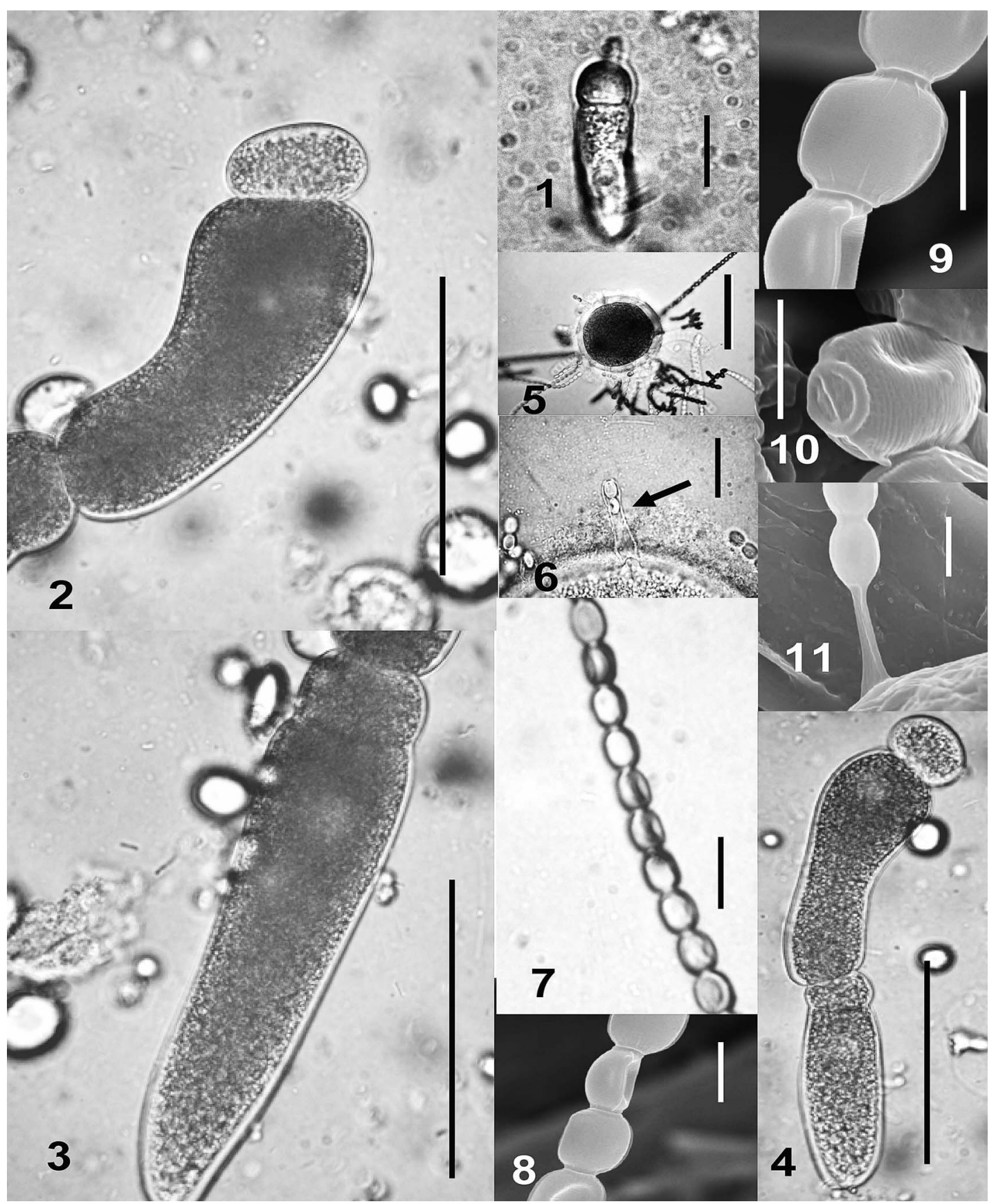

FIGURES 1-11. Awrygregarina billmani, n. sp. in various stages. (1) Young trophozoite with epimerite. Bar $=10 \mu \mathrm{m}$. (2-3) Primite and satellite of associated pair, respectively. Bar $=100 \mu \mathrm{m}$. (4) Smaller associated pair. Bar $=50 \mu \mathrm{m}$. (5) Gametocyst in dehiscence (in glycerin). $\mathrm{Bar}=100 \mu \mathrm{m}$. (6) Oocyst tube (arrow) on gametocyst; oocysts allow estimation of tube length. Bar $=20 \mu \mathrm{m}$. (7) Oocyst chain. Bar $=10 \mu \mathrm{m}$. (8-10) Oocysts (SEM) showing ends and fine circumferential striations. Bar $=5 \mu \mathrm{m}$. (11) Oocysts showing what appear to be an external sheath binding them into a chain.

pearance of the compartment being awry or askew in comparison to typical species of Gregarina.

\section{Remarks}

Dehiscence in chains through sporoducts, precocious association, and cephalocaudal association, all consistent with cardinal characters of the Gregarinidae. Oocyst ultrastructural characters, especially nature of fine surface striations, clearly distinguish this genus from those currently considered species of Gregarina and for which SEM-level oocyst characters are available. Major distinguishing feature of this genus, sepa- rating it from Gregarina, is oocyst surface architecture as revealed by SEM. Series of low ridges encircling oocyst parallel to equator is in stark contrast to high longitudinal ridges characteristic of Gregarina species from congeneric hosts.

\section{Awrygregarina billmani $\mathrm{n} . \mathrm{sp}$. (Figs. 1-19)}

Trophozoite (Figs. 1, 12-13): Developing trophozoites attached to host epithelium; primites and satellites distinguishable at all developmental stages by offset protomerite (primite) and attenuated posterior 


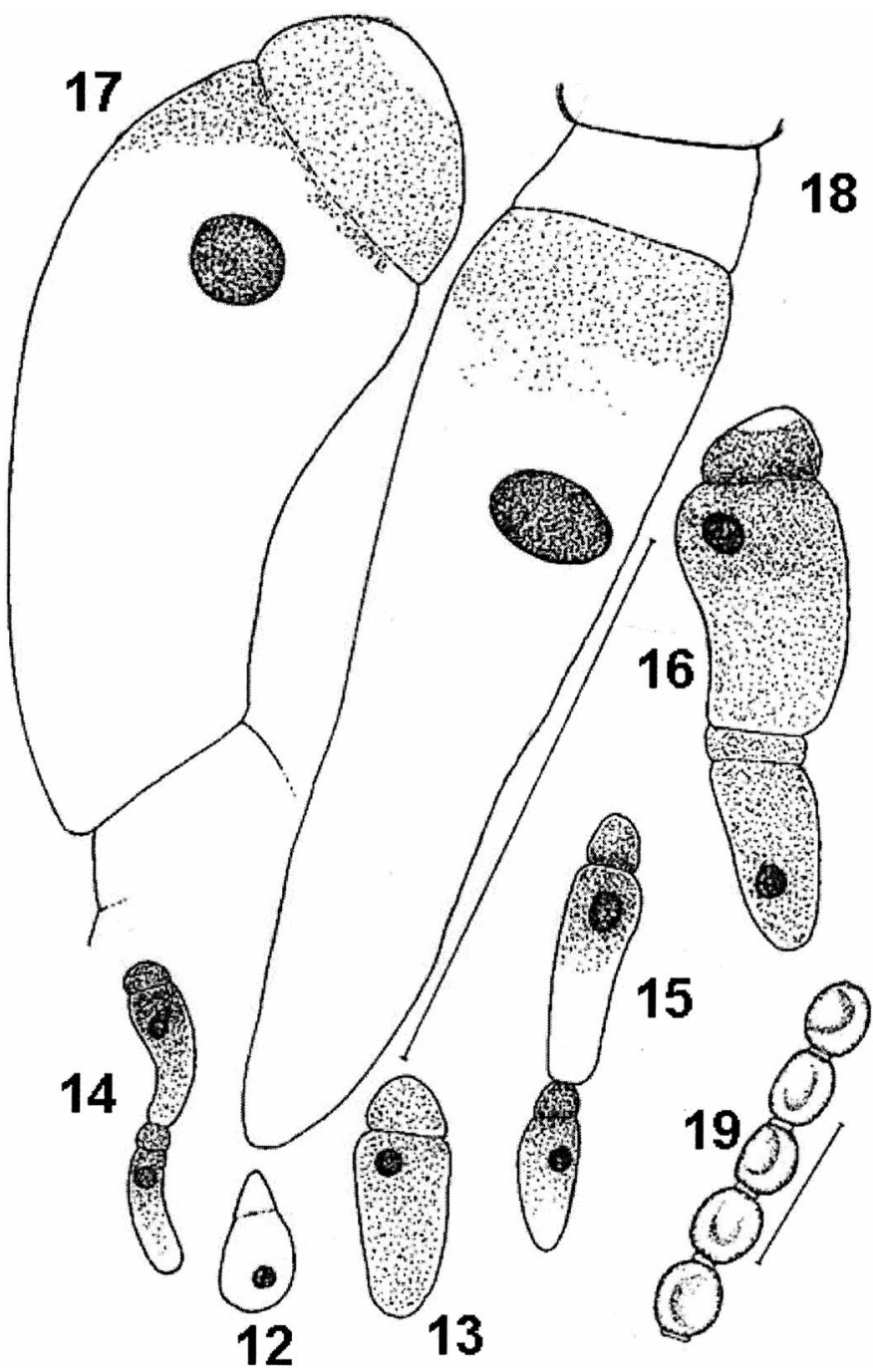

FiguRES 12-19. Line drawings of Awrygregarina billmani, n. sp. (12-13) Young trophozoites. (14-16) Paired gamonts in various stages of maturity. (17) Mature associated primite. (18) Mature associated satellite. (19) Oocysts. Figures 12-18, bar $=100 \mu \mathrm{m}$; Figure 19, bar $=10 \mu \mathrm{m}$.

end (satellite); epimerite papillalike, visible usually only on smallest trophozoites. Measurements and correlations between measurements are listed in Table II.

Gamonts and association (Figs. 2-4, 14-18): Primite: protomerite ovoid to broadly ovoid, tilted away from primite axis; deutomerite oblong to narrowly oblong. Satellite: protomerite ovoid to broadly ovoid; deutomerite obovoid to narrowly obovoid. Measurements and correlations between measurements in Table II.

Gametocysts (Figs. 5-6): Spherical to oval, white translucent when shed, with obvious sporoducts when allowed to dehisce in 1:1 glycerin: water; $119.1(95.0-142.5,11.3,15)$ by $102.6(85.5-123.5,10.9,15)$.

Oocysts (Figs. 7-11, 19): Broadly dolioform, in chains, often depressed or somewhat concave on 1 surface; length 4.8 (3.7-5.5, 0.4, $50)$, width $3.5(2.9 \times 4.1,0.3,50)$, thickness $2.2(1.6-2.8,0.2,50)$, Ultrastructurally with a coating, presumably of gametocyst origin, over oocyst chain, series of low ridges or fine striations parallel to equator, and raised ring at each end of each oocyst (Figs. 8-10).

\section{Taxonomic summary}

Host: Tribolium brevicornis LeConte, 1859.

Symbiotype: University of Nebraska State Museum, Entomology Division collection, vouchers: J. Janovy, Jr. 001-010 (10 pinned adults on points); J. Janovy, Jr., 050 (larvae in vial).

Host records: Tribolium brevicornis LeConte, 1859; larvae; laboratory infections.
Locality: University of Nebraska Lincoln; School of Biological Sciences, Manter Hall, Lincoln, Nebraska, cultures.

Infection site: Midgut.

Specimens: University of Nebraska State Museum, Harold W. Manter Laboratory of Parasitology collections; HWML48434 (hapantotype); HWML48435-HWML48438 (paratypes).

Etymology: The new species is named in honor of Dr. James K. Billman, Jr., a generous supporter of University of Nebraska undergraduate research and teaching, especially at the Cedar Point Biological Station.

\section{Remarks}

"Trophozoites" include individuals that for some reason remain unassociated, thus this stage is designated rather arbitrarily, given that some are obviously very tiny and others are very large. In the case of Awrygregarina billmani, presumptive primites and satellites have morphological features that allow one to distinguish the 2 mating types while they are still very small, and the 2 types retain characteristic morphology even if they remain singlets until they grow relatively large. Epimerites are visible only on the very small ones; however, designation of these individuals as "immature" is arbitrary because epimerites can be lost in dissection or in the process of making permanent slides from smears. Minimum pairing size is one potentially useful criterion for distinguishing immature from mature trophozoites, although the term "precocious" as applied to pairing, and used as a taxonomic character, 


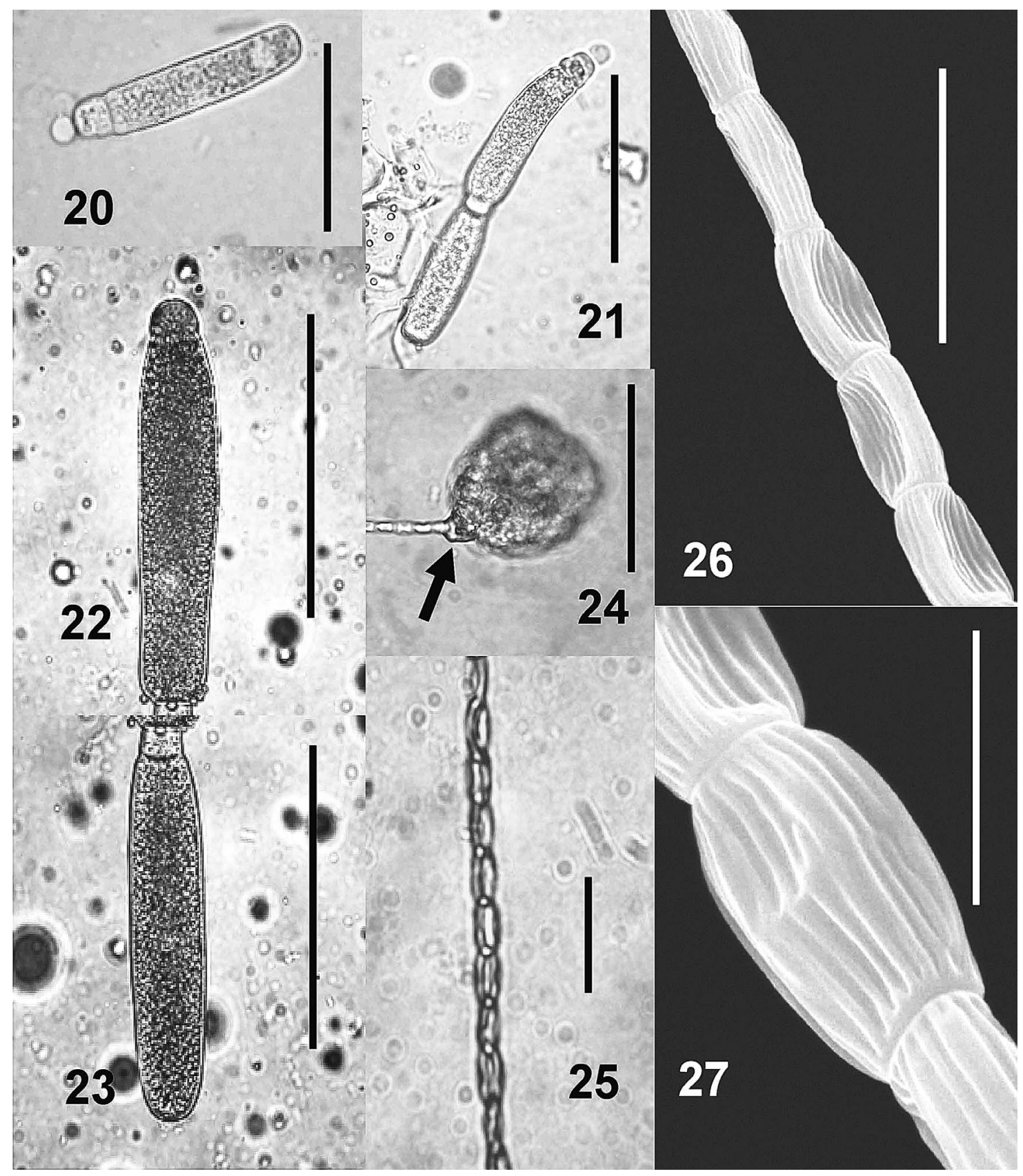

FIGURES 20-27. Gregarina cloptoni, n. sp., various stages. (20) Young trophozoite. Bar $=50 \mu \mathrm{m}$. (21) Immature associated pair, showing epimerite. Bar $=50 \mu \mathrm{m}$. (22-23) Mature primite and satellite, respectively. Bar $=100 \mu \mathrm{m}$. (24) Gametocyst showing sporoduct (arrow). Bar $=$ $100 \mu \mathrm{m}$. (25) Oocysts. Bar = $10 \mu \mathrm{m}$. (26-27) SEMs of oocysts showing longitudinal ridges (Fig. 26, bar = $10 \mu \mathrm{m}$; Fig. 27, bar = $5 \mu \mathrm{m}$ ).

tends to call this criterion into question. It is obvious from the literature that gregarine mating behavior is quite diverse, but generally falls into 2 categories, i.e., late and precocious. Awrygregarina billmani pairs precociously, but some individuals do not find mates. Failure to pair does not inhibit growth because singlets can grow as large as their mated co-symbionts.

\section{Gregarina cloptoni n. sp.} (Figs. 20-33)

Trophozoite (Figs. 20, 28-29): Epimerite globular. Protomerite shallow to broadly ovoid; deutomerite narrow to very narrowly oblong.
Measurements and correlations between measurements are given in Table II.

Gamonts and association (Figs. 21-23, 31-32): Primite: TL 111.1 (46.0-214.0, 37.0, 68); protomerite very shallow to broadly ovoid; deutomerite narrow to very narrowly oblong. Satellite: protomerite depressed to shallowly ovoid; deutomerite narrow to very narrowly oblong. Measurements and correlations between measurements in Table II.

Gametocysts (Fig. 24): Translucent and white when shed, with hyaline space up to $10 \mu$ wide surrounding inner cytoplasmic mass; subspherical, $94.4(85.5-104.5,5.6,15)$ by $87.4(76.0-95.0,6.2,15)$.

Oocysts (Figs. 25-27, 33): In chains, end-to-end with long axis par- 


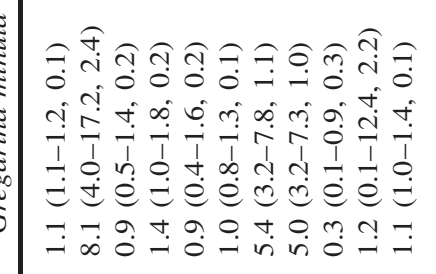

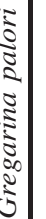

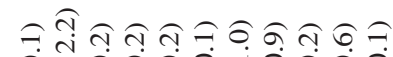

000000000

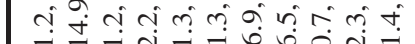

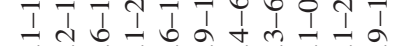

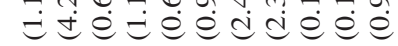

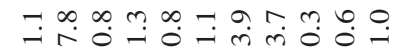

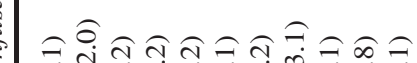

0 n. 0000.90000

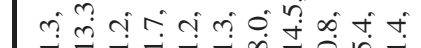

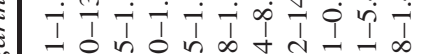

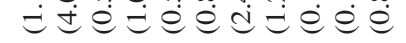

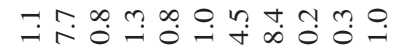

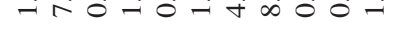

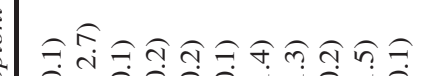

0 incon 0

mं ती mं की

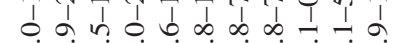

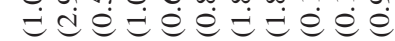

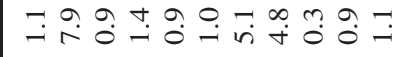

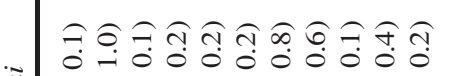

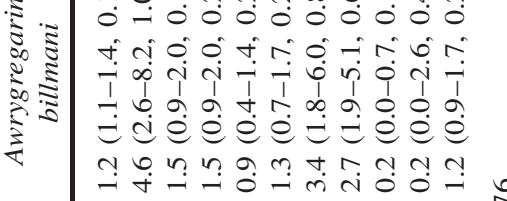

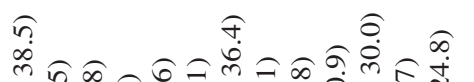

m

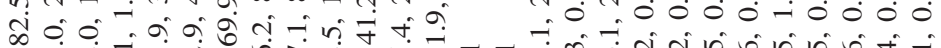

我它

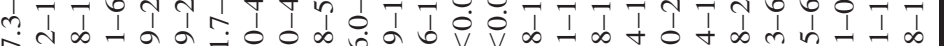

वृ

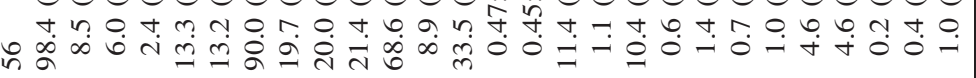

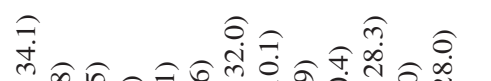

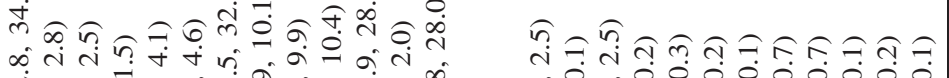

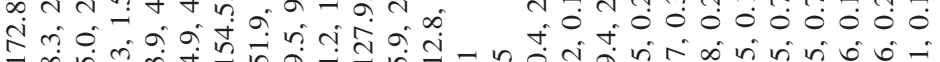
-

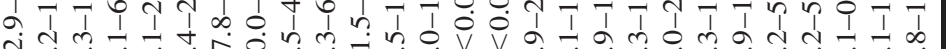
Jैu

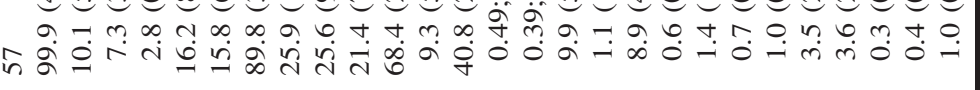

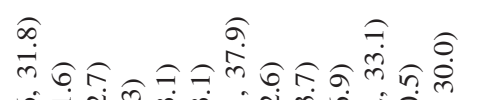

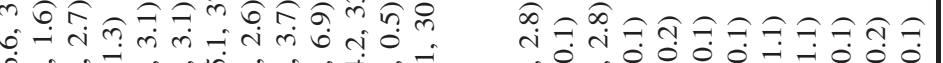

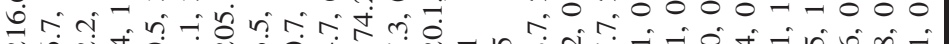

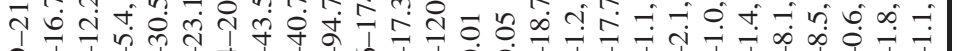

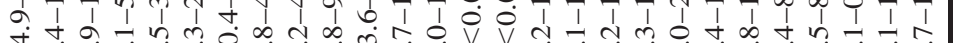

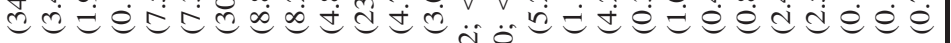

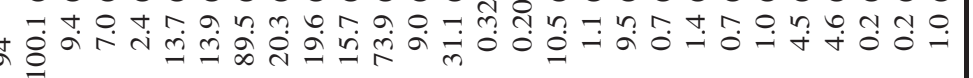

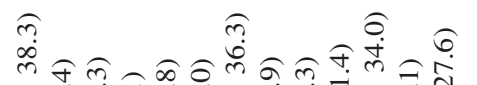

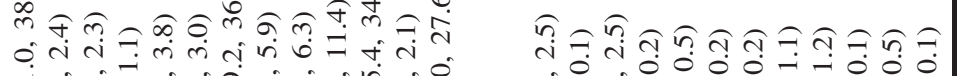
- o n m I $=$ 我

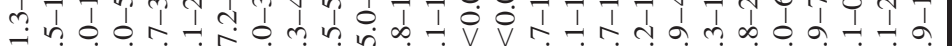
कृ

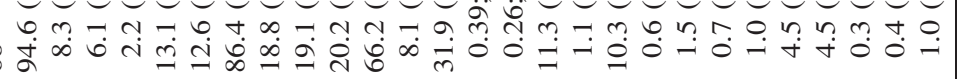

ते

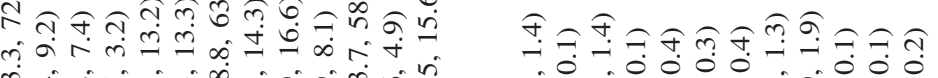

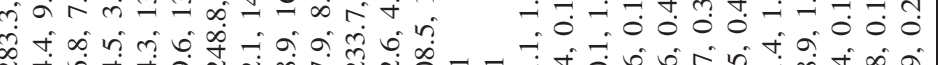
१ै

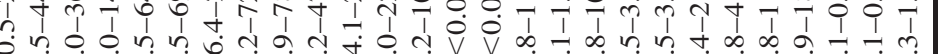

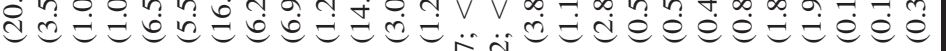

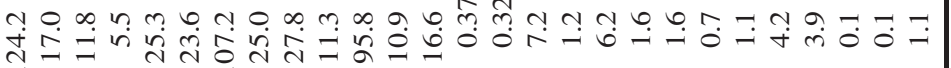

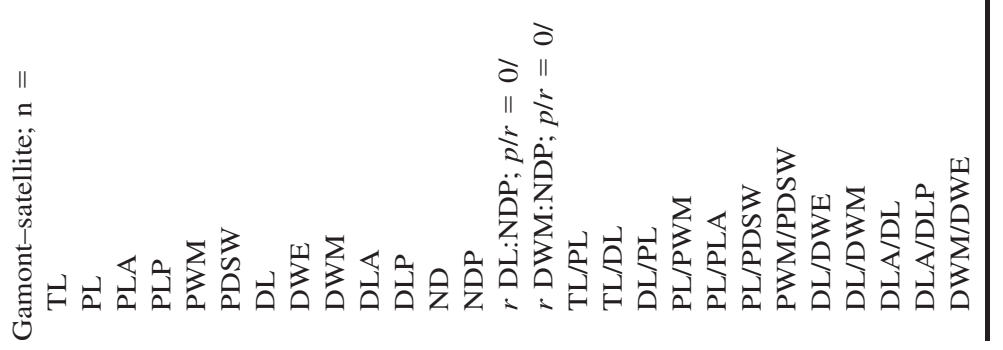




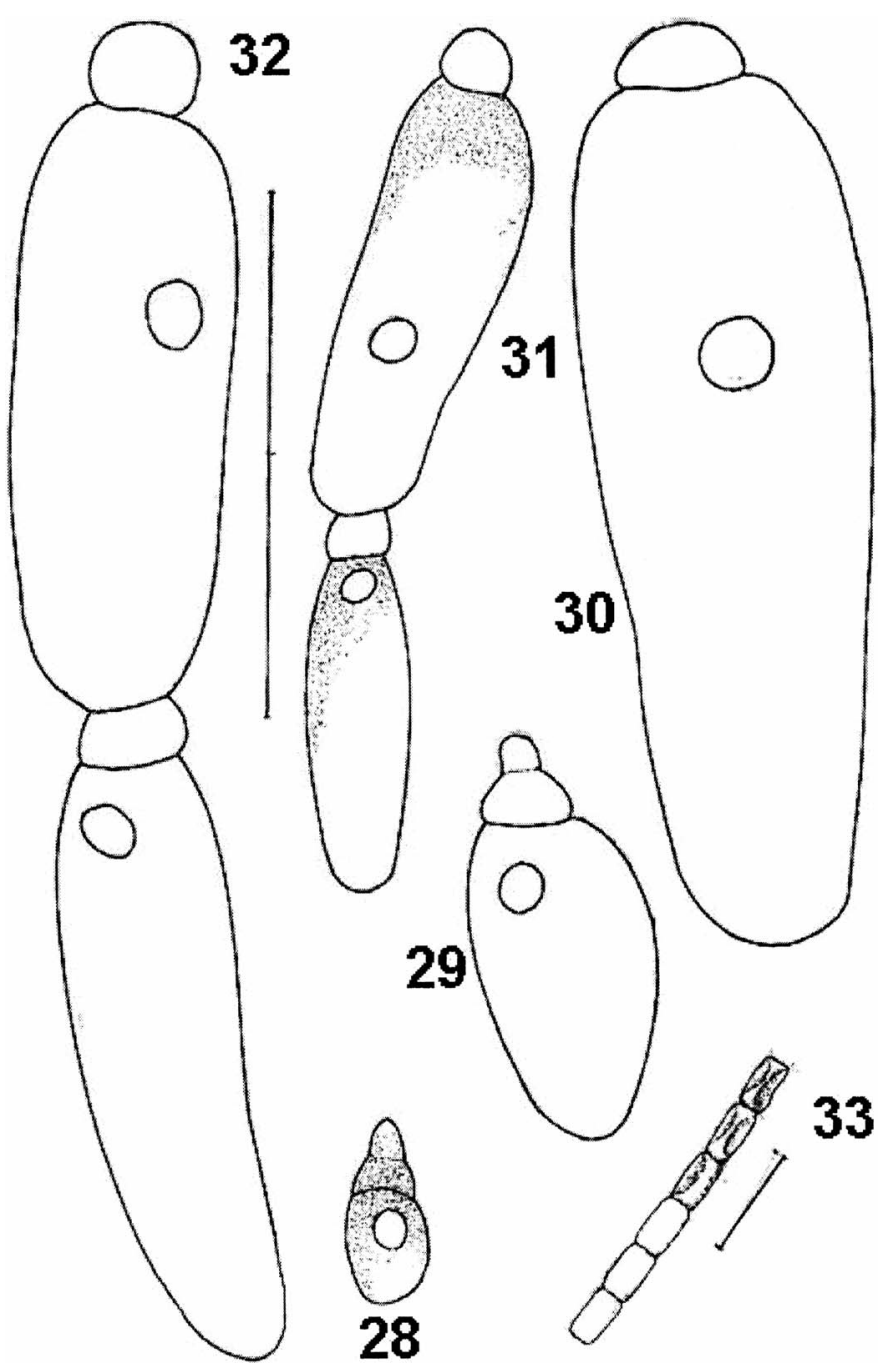

Figures 28-33. Gregarina cloptoni, n. sp. (28-30) Trophozoites of various ages. (31) Immature associated pair. (32) Mature associated pair. (33) Oocysts. Figures 28-32, bar $=100 \mu \mathrm{m}$; Figure 33, bar $=10 \mu \mathrm{m}$

allel to chain axis but with individual cysts rotated at various angles along axis; oblong, irregularly wrinkled, indented, or compressed when dry; length $5.4(4.6-6.3,0.4,50)$, width $2.9(2.4-3.5,0.3,50)$, thickness $1.8(1.2-2.6,0.3,50)$. Ultrastructurally with series of ridges parallel to long axis (Figs. 26-27)

\section{Taxonomic summary}

Host: Tribolium freemani Hinton 1949.

Symbiotype: University of Nebraska State Museum, Entomology Division collection, vouchers: J. Janovy, Jr., 031-040 (10 pinned adults on points); J. Janovy, Jr., 053 (larvae in vial).

Host records: Tribolium freemani Hinton 1949 (larvae; laboratory infections).

Locality: University of Nebraska Lincoln; School of Biological Sciences, Manter Hall, Lincoln, Nebraska, cultures.

Infection site: Midgut.

Specimens: University of Nebraska State Museum, Harold W. Manter Laboratory of Parasitology collections; HWML48446 (hapantotype); HWML48439-HWML48445 (paratypes).

Etymology: The specific epithet is given in honor of Dr. Richard Clopton, who, with his series of recent taxonomic papers, has established the standards of gregarine species-level systematics.

\section{Remarks}

Gregarina cloptoni differs from other Gregarina spp. described from flour beetles in having a globular epimerite that often persists in the gamonts and in having larger gametocysts than G. palori, G. minuta, or $G$. confusa. In addition, among the 4 gregarine species described and redescribed from Tribolium species in this article, oocyst measurements differ significantly when tested by ANOVA; for lengths, $F=73.7$ (3, 196), widths, $F=50.4$ (3, 196), and thicknesses, $F=6.3(3,196)$. Gregarina cloptoni oocysts are narrower than those of either G. palori or G. minuta, but wider than those of G. confusa.

\section{Gregarina confusa n. sp.}

(Figs. 34-47)

Trophozoite (Figs. 34, 41-43): Epimerite, a long cone. Protomerite very shallowly to broadly ovoid; deutomerite narrowly to very narrowly oblong. Measurements and correlations between measurements in Table II.

Gamonts and association (Figs. 35-36, 44-46): Primite: protomerite broad to very broadly ovoid; occasionally with epimerite; deutomerite narrow to very narrowly oblong. Satellite: protomerite shallow to broadly ovoid; deutomerite narrow to very narrowly oblong. Measurements and correlations between measurements in Table II. 


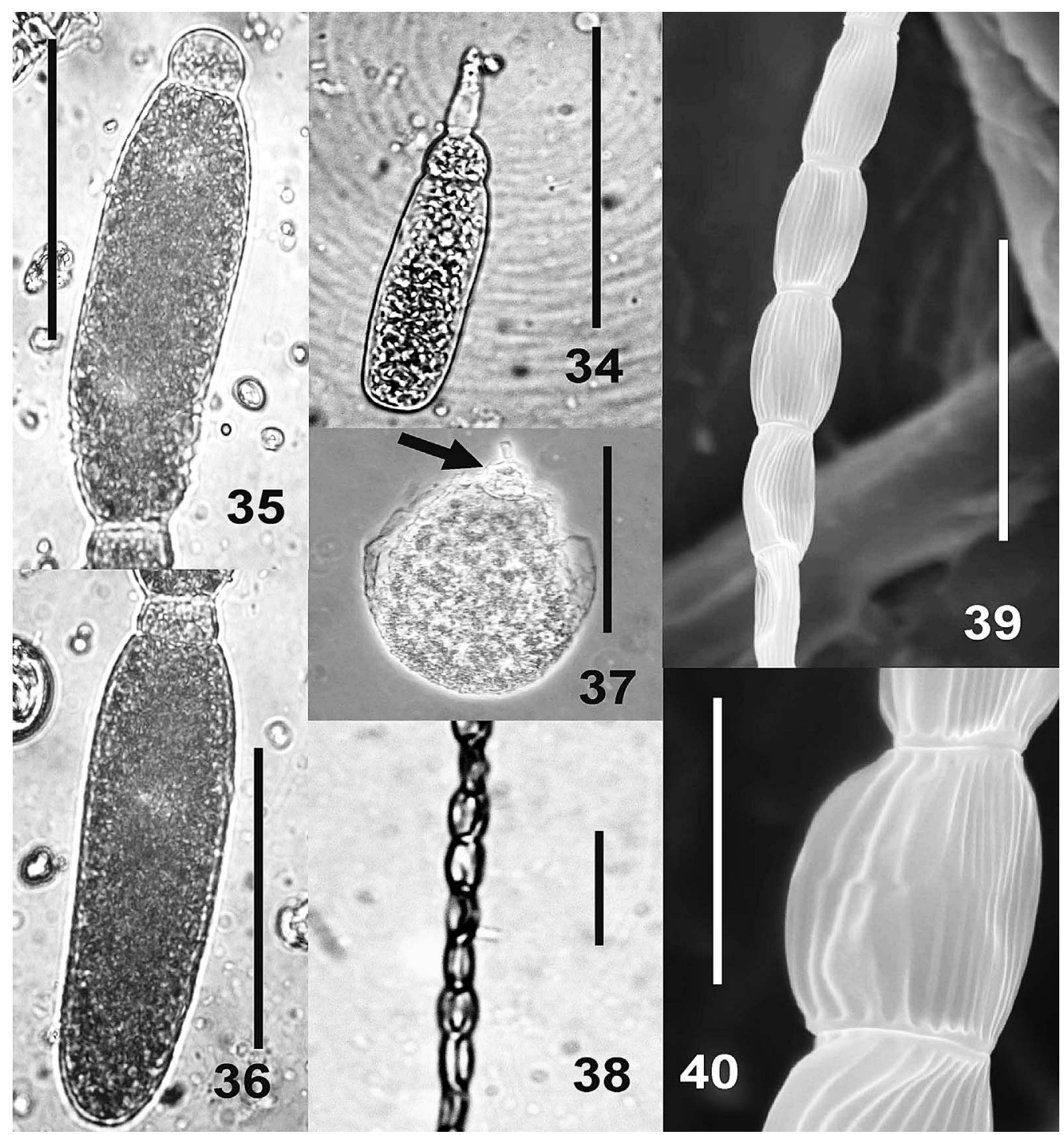

Figures 34-40. Gregarina confusa, n. sp. various stages. (34) Young trophozoite. Bar $=50 \mu \mathrm{m}$. (35-36) Mature associated pair, primite and satellite, respectively. Bar $=100 \mu \mathrm{m}$. (37) Gametocyst with sporoduct (arrow). Bar $=100 \mu \mathrm{m}$. (38) Oocyst chain. Bar $=10 \mu \mathrm{m}$. (39-40) SEMs of oocysts (Fig. 39, bar $=10 \mu \mathrm{m}$; Fig. 40 , bar $=5 \mu \mathrm{m}$ ).

Gametocysts (Fig. 37): Translucent and white when shed, with a hyaline space up to $10 \mu \mathrm{m}$ wide surrounding inner cytoplasmic mass; subspherical to broadly ellipsoid, variable in size; 82.3 (57.0-95.0, 10.6, $15)$ by $75.4(57.0-90.3,10.9,15)$.

Oocysts (Figs. 38-40, 47): In chains, end-to-end, with long axis parallel to chain axis but with individual cysts rotated at various angles along axis; oblong, irregularly wrinkled, indented, or compressed when dry; length $4.8(3.3-6.3,0.8,50)$, width $2.6(2.0-3.3,0.3,50)$, thickness $1.7(1.0-2.6,0.4,50)$. Ultrastructurally with series of ridges parallel to long axis (Figs. 39-40).

\section{Taxonomic summary}

Host: Tribolium confusum Jacquelin du Val, 1868.

Symbiotype: University of Nebraska State Museum, Entomology Division collection, vouchers: J. Janovy, Jr., 021-030 (10 pinned adults on points); J. Janovy, Jr., 052 (larvae in vial).

Host records: Tribolium confusum Jacquelin du Val, 1868; larvae; laboratory infections.

Locality: University of Nebraska Lincoln; School of Biological Sciences, Manter Hall, Lincoln, Nebraska, cultures.

Infection site: Midgut.

Specimens: University of Nebraska State Museum, Harold W. Manter
Laboratory of Parasitology collections; HWML48449 (hapantotype); HWML48447-HWML48448 and HWML48450-48451 (paratypes).

Etymology: The specific epithet is derived from that of the type host.

\section{Remarks}

The major feature distinguishing $G$. confusa from the other described gregarines parasitizing Tribolium species is the elongate cone epimerite. None of the published descriptions of gregarines from flour beetles shows or indicates such an epimerite. In fresh preparations, this epimerite begins to swell into a bubble basally, likely in response to osmotic pressure, as if the membranes were relatively fragile at this particular place on the cell surface. In trophozoites, the protomerite is also relatively shorter than in the other species (TL/PL $=8.7$ for $G$. confusa vs 7.6-8.6 for the others). Finally, the G. confusa oocysts are smaller than those of the other species described in this article.

\section{Gregarina palori $\mathrm{n}$. sp.}

(Figs. 48-61)

Trophozoite (Figs. 48, 55-57): Epimerite spherical or subspherical, subequal in size to protomerite. Protomerite shallow to broadly ovoid; 


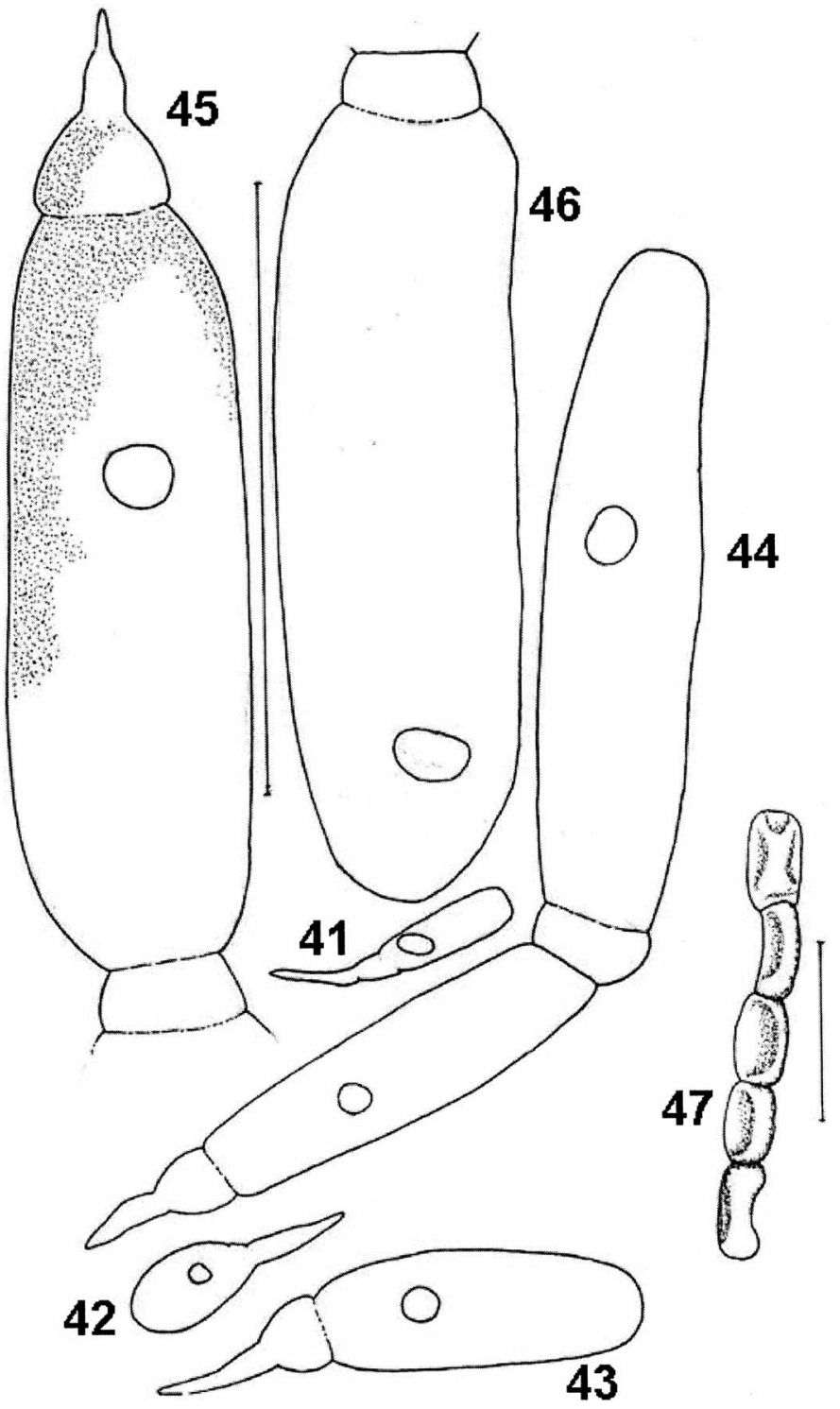

FiguREs 41-47. Gregarina confusa, n. sp. (41-43) Trophozoites of different ages. (44) Immature associated pair. (45-46) Mature associated pair, primite and satellite, respectively. (47) Oocyst chain. Figures 41-46, bar $=100 \mu \mathrm{m}$; Figure 47, bar $=10 \mu \mathrm{m}$.

deutomerite narrow to very narrowly oblong. Measurements and correlations between measurements in Table II.

Gamonts and association (Figs. 49-50, 58-60): Primite: epimerite sometimes present; protomerite shallow to broadly ovoid; deutomerite narrow to very narrowly oblong. Satellite: protomerite very shallow to very broadly ovoid; deutomerite oblong to very narrowly oblong. Measurements and correlations between measurements in Table II.

Gametocysts (Fig. 51): Subspherical, with obvious cyst wall of uniform thickness; $75.8(52.3-104.5,17.5,20)$ by $69.1(47.5-90.0,16.4$ 20).

Oocysts (Figs. 52-54, 61): In chains, end-to-end, with long axis parallel to chain axis, but with individual cysts rotated at various angles along axis; oblong, irregularly wrinkled, indented, or compressed when dry; length $6.6(4.9-8.5,0.8,50)$; width $3.2(2.4-4.3,0.5,50)$; thickness $1.9(1.3-2.5,0.3,50)$. Ultrastructurally with series of ridges parallel to long axis (Figs. 53-54).

\section{Taxonomic summary}

Host: Palorus subdepressus Wollaston 1864.

Symbiotype: University of Nebraska State Museum, Entomology Di- vision collection, vouchers: J. Janovy, Jr., 041-049 (9 pinned adults on points); J. Janovy, Jr., 054 (larvae in vial).

Host records: Palorus subdepressus Wollaston, 1864; larvae; laboratory infections.

Locality: University of Nebraska Lincoln; School of Biological Sciences, Manter Hall, Lincoln, Nebraska, cultures.

Infection site: Midgut.

Specimens: University of Nebraska State Museum, Harold W. Manter Laboratory of Parasitology collections; HWML48452 (hapantotype); HWML48453-HWML48457 (paratypes).

Etymology: The specific epithet is derived from that of the type host.

\section{Remarks}

Although the larva is designated as the stage from which this parasite is described, virtually identical parasites are found in adults in the same culture. Experimental evidence from this laboratory indicates that uninfected adults can be infected with G. palori oocysts from gametocysts shed by larvae (Detwiler, 2004). The gametocysts are the smaller than those of G. confusa, G. cloptoni, and G. minuta, but the oocysts are the largest among the 4 Gregarina species described in this article. 


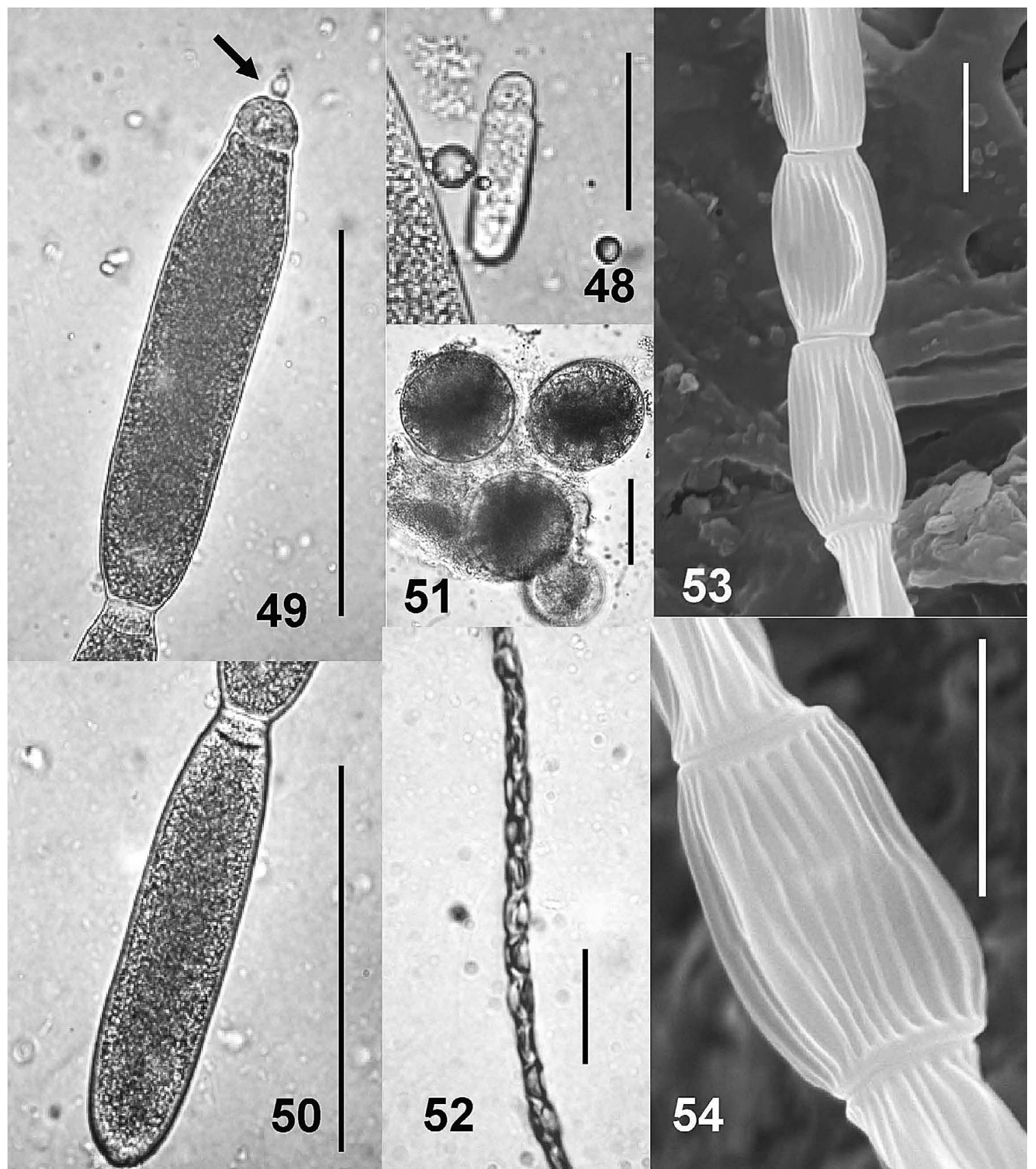

FiguRES 48-54. Gregarina palori, n. sp. various stages. (48) Young trophozoite. Bar $=30 \mu \mathrm{m}$. (49-50) Mature associated pair, primite and satellite, respectively. Bar $=100 \mu \mathrm{m}$. (51) Gametocysts. Bar $=50 \mu \mathrm{m}$. (52) Oocyst chain. Bar $=10 \mu \mathrm{m}$. (53-54) SEMs of oocysts showing longitudinal ridges. Bar $=5 \mu \mathrm{m}$ in Figures 53-54.

\section{EMENDED DESCRIPTION}

\section{Gregarina minuta Ishii, 1914} (Figs. 62-74)

Trophozoite (Figs. 62, 69-70): Epimerite elongate globular or slightly conical. Protomerite ovoid to broadly ovoid; deutomerite oblong to very narrowly oblong. Measurements and correlations between measurements in Table II.

Gamonts and association (Figs. 63-64, 71-73): Primite: protomerite very shallow to broadly ovoid; deutomerite narrow to very narrowly oblong. Satellite: protomerite very shallow to broadly ovoid; deutomerite narrow to very narrowly oblong. Measurements and correlations between measurements in Table II.

Gametocysts (Fig. 65): Translucent and white when shed, often with hyaline space up to $10 \mu \mathrm{m}$ wide surrounding inner cytoplasmic mass; subspherical to broadly ellipsoid, quite variable in size; 76.2 (47.5$104.6,16,23)$ by $72.5(57.0-90.3,11.0,23)$.

Oocysts (Figs. 66-68, 74): In chains, end-to-end, with long axis parallel to chain axis but with individual cysts rotated at various angles along axis; oblong, irregularly wrinkled, indented, or compressed when dry; length $5.6(4.4-6.5,0.4,50)$, width $3.4(3.0-3.8,0.2,50)$, thickness 


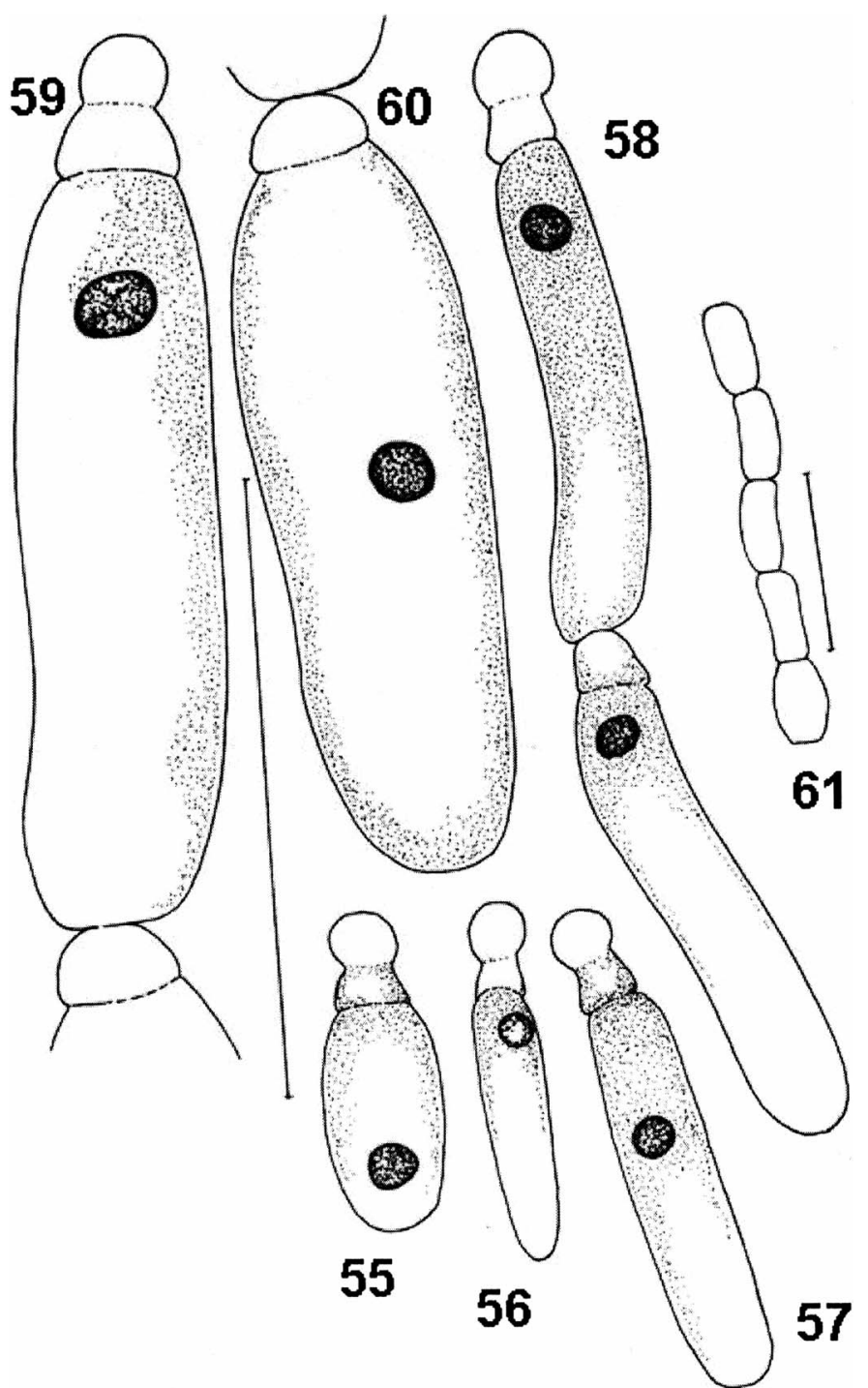

FiguRES 55-61. Gregarina palori, n. sp. (55-57) Trophozoites of different ages, showing globular epimerites. (58) Immature associated pair. (59-60) Mature associated pair, primite and satellite, respectively. (61) Oocyst chain. Figures 55-60, bar $=100 \mu \mathrm{m}$; Figure 61, bar $=10 \mu \mathrm{m}$.

$1.9(1.3-2.3,0.3,50)$. Ultrastructurally with series of ridges parallel to long axis (Figs. 67-68).

\section{Taxonomic summary}

Host: Tribolium castaneum (Herbst, 1797) Good, 1936 (= Tr. ferrugineum Wollaston, 1854).

Symbiotype: University of Nebraska State Museum, Entomology Division collection, vouchers: J. Janovy, Jr., 011-020 (10 pinned adults on points); J. Janovy, Jr., 051 (larvae in vial).

Host records: Larvae of Tribolium castaneum (Herbst, 1797) Good, 1936 (= Tr. ferrugineum Wollaston, 1854); larvae; laboratory infections.

Locality: University of Nebraska Lincoln; School of Biological Sciences, Manter Hall, Lincoln, Nebraska, cultures.

Infection site: Midgut.

Specimens: University of Nebraska State Museum, Harold W. Manter Laboratory of Parasitology collections; HWML48458 (hapantotype); HWML48459-HWML48463 (paratypes).

\section{Remarks}

Ishii (1914) described G. minuta from the adults of Tr. ferrugineum, a host species now considered synonymous with $\mathrm{Tr}$. castaneum. This description actually refers to Figure $2 \mathrm{~b}$ of Ishii (1914); Figure 2a in the Ishii (1914) article is a different species, G. triboliorum, and Figure 2c from that article could be a singlet of either species, although it is most likely one of G. minuta. (See Watwood et al. [1997] for resolution of the confusion surrounding these 2 species in the same host beetle.) A complete discussion of host nomenclatural history is found in Good (1936), and the decision to designate larval $\mathrm{Tr}$. castaneum as the type host is based on that discussion. Experimental evidence from this laboratory indicates that uninfected adult beetles can be infected with $G$. minuta oocysts from gametocysts shed by larvae (Detwiler, 2004). The present description adds the Clopton $(1999,2004 a)$ extended morphometric data set and shape nomenclature; epimerite shape, gametocyst and oocyst description, and measurements; and SEM micrographs of oocysts to the description. With these measurements and descriptors, Gregarina minuta is thus distinguished clearly from G. triboliorum Watwood et al., 1997, another species found in Tr. castaneum. Gregarina triboliorum not only loses the satellite protomerite very early in development but also exhibits a finely granular cytoplasm that is easily recognized as different from the coarser cytoplasm of G. minuta on stained smears. The elongate cone-shaped epimerite of G. minuta is fragile near the base, and even in Tenebrio saline, its membrane tends to form a bubble, evidently from uptake of water.

Measurements of the emended description are larger than those re- 


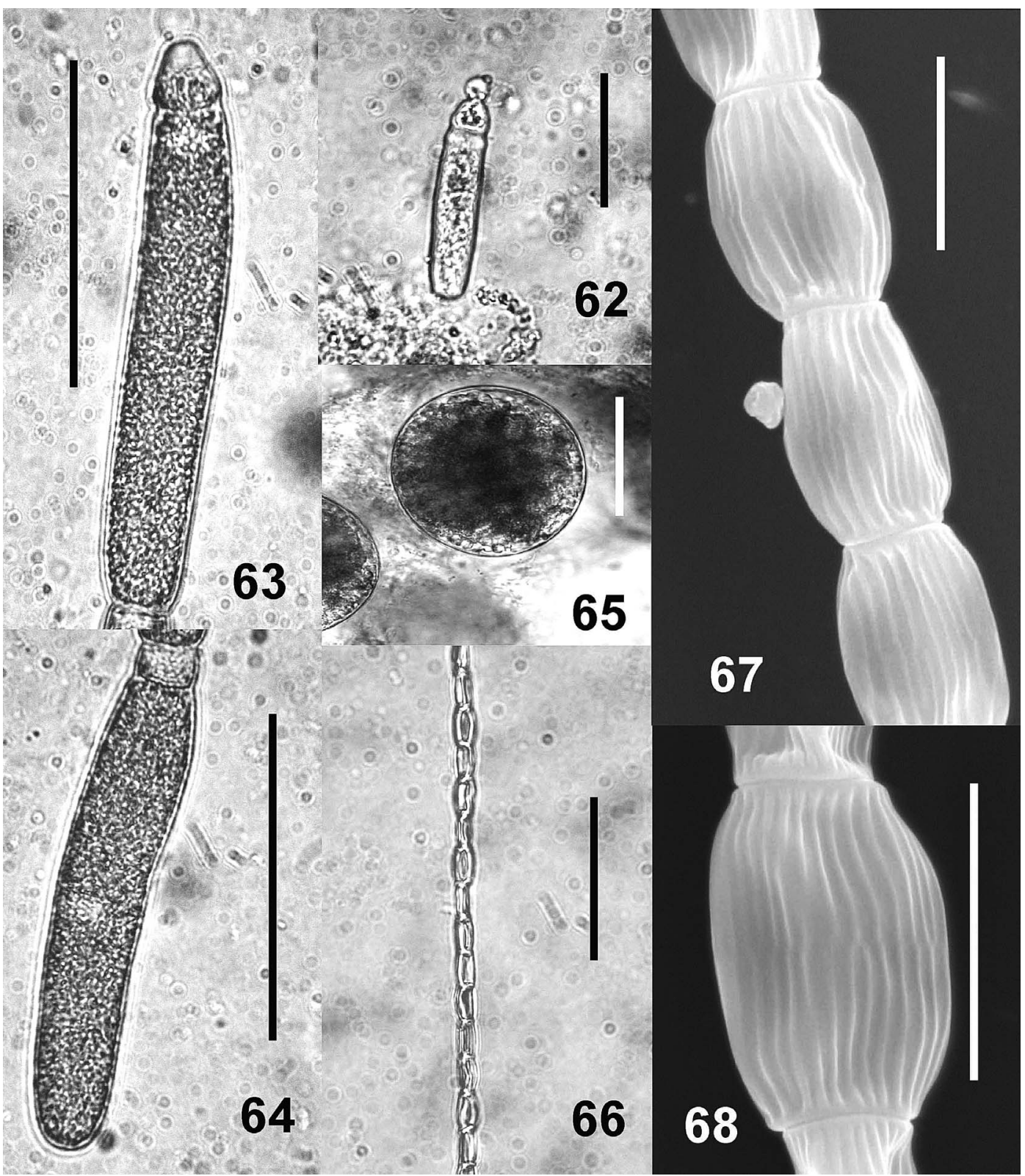

FIGURES 62-68. Gregarina minuta, various stages. (62) Young trophozoite. Bar $=30 \mu \mathrm{m}$. (63-64) Associated pair, primite and satellite, respectively. Bar $=100 \mu \mathrm{m}$. (65) Gametocyst. Bar $=50 \mu \mathrm{m}$. (66) Oocyst chain. Bar $=25 \mu \mathrm{m}$. (67-68) SEMs of oocysts showing longitudinal ridges. Bar $=5 \mu \mathrm{m}$ in Figures $67-68$.

ported by Ishii (1914) for G. minuta, but Ishii (1914) does not indicate whether adult or larval hosts were used in the study, and neither numbers of observations and ranges nor ratios suggesting body proportions are given. The decision to amend the Ishii (1914) description, rather than describe another new species from this same host species, is based on the persistent satellite protomerite in the present study material and the uncertainty of the number of measurements and their ranges in the original description.

A number of other gregarine taxa have been described from Tr. castaneum, especially by workers in India (e.g., Ghose et al., 1986; Gupta and Haldar, 1987; Ghose and Haldar, 1989; Sengupta et al., 1991; Saha et al., 1995). In general, it is possible to distinguish these genera and species from ones reported in this article, but in some cases the distinctions are not clear. Gregarine descriptions published before Clopton (1999, 2004a) do not include all of the measurements and characters now commonly used and often do not distinguish between primites and satellites. In the case of G. minuta, oocyst shape separates this species from all of those described by the Indian workers cited above.

\section{DISCUSSION}

The major contribution of this article is the provision of a described and domesticated system for the study of several species of related parasites among a set of congeneric and confamilial host species, all of which are easily maintained in culture. Thus, we are in a position to begin asking whether the 2 host and parasite phylogenies are congruent, or whether there is evidence for independent acquisition of parasite taxa by host taxa. This question is not a particularly new one, nor is it unique to coleopterans and their apicomplexan parasites. With this taxo- 


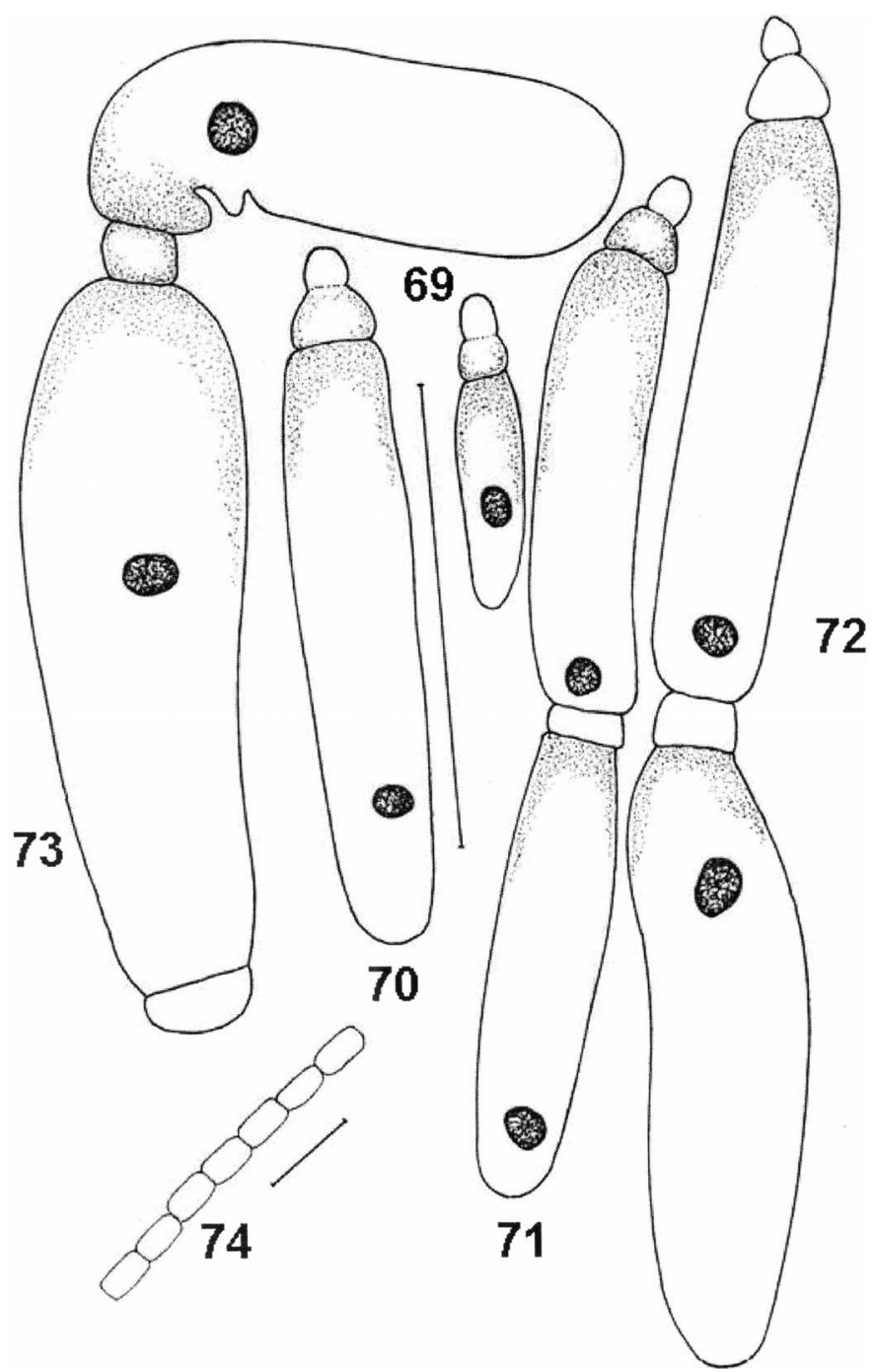

FiguRES 69-74. Gregarina minuta. (69-70) Trophozoites of differing ages. (71-72) Associated gamonts, showing persistent epimerites. (73) Mature associated gamonts. (74) Oocyst chain. Figures 69-73, bar $=100 \mu \mathrm{m}$; Figure 74, bar $=10 \mu \mathrm{m}$.

nomic work, however, one can begin to address the question of whether phylogenies constructed after the fact of their origin can actually hide attributes that either influenced that origin or could constrain a host species list for a particular parasite species, thus potentially directing future evolutionary change. For example, with the gregarine-flour beetle system, we can determine experimentally whether a parasite from 1 host species can, if given the opportunity, infect related hosts. Multispecies systems amenable to such experimental exploration of avenues for evolutionary change are not common, especially when one considers logistical constraints associated with the potential use of many reasonably well-studied taxa as laboratory models (e.g., see Snyder and Tkach, 2001; León-Règagnon and Brooks, 2003; Caira et al., 2005).

Anyone familiar with gregarine systematic literature will immediately recognize that the descriptions herein are based at least partly on the principle of "new host studied, new parasite discovered." This principle has guided gregarine taxonomy for many decades and, although it is not necessarily an advisable one to follow in all instances (e.g., see Watwood et al., 1997), it is an acceptable one in the present case. We contend that with respect to gregarines in flour beetles, it is more important at this stage in the development of our understanding of gregarine biology to have a scientific name, a describer and date, and a set of characters consistent with current practice, all in print, than it is to engage in years of research, trying to establish whether species are valid. Oocyst lengths, widths, and thicknesses differ significantly among the described species, and there are certainly epimerite shape differences between some of the species. With these descriptions, it is now possible to do the experimental infection work that could reveal host-induced variation; avenues for, and constraints on, colonization; effects of host-induced variation in parasite attributes; and possible pathogenic effects of parasites in unusual hosts. Most important, however, this work now allows us to determine whether, within a group of related parasites, generalists (infecting 2 or more host species) and specialists (restricted to a single host species) occur. Much of this kind of research, however, must await appropriate molecular studies on this group of parasites.

In addition to the above issues regarding gregarine system- 
atics, it is also necessary to recognize that gregarine morphology is not easy to describe satisfactorily, and indeed, the conventions of measurement may lead a naïve reader astray. The growing body of recent taxonomic work by Clopton and coworkers (Clopton, 1999, 2000, 2004a, 2004b; Clopton et al., 2004) has done much to resolve this problem, but there is really no way to avoid certain descriptive difficulties associated with gregarine development. For example, the terms "trophont" or "trophozoite" seem to be well-defined ones, but this life-cycle stage is so designated because the individual cells are neither obviously associated nor otherwise exhibit visual evidence of commitment to gametogenesis. Association, again by definition, signifies that the cells have become "gamonts" or "gametocytes." But some species are precocious, associating early in development, whereas others associate late. Phasing of association has been mentioned as a taxonomic character at both the generic and family levels (Kula and Clopton, 1999; Clopton, 2000). The present study suggests that the timing of association is variable enough within a group of congeners so that it could also be used at even the species level, provided structural features map onto developmental ones. However, phasing of association could also be influenced by host species and diet, a facet of gregarine biology that has yet to be explored but could easily be investigated with the flour beetle-gregarine system.

The oocyst SEMs in this article are also an important contribution to the gregarine literature. From these pictures, we discover that oocysts seeming to differ primarily in their outlines as viewed from one of the broadest dimensions, especially under the light microscope suspended in glycerin, can in fact be quite distinct in their surface architecture. The examination of oocyst measurements and apparent structure under different observational environments also reveals information of use in systematics. Insofar as can be determined using light microscopy, oocysts of the Gregarina species studied are irregularly wrinkled, in addition to being ridged, when observed dry, as they would occur in nature. When flooded with glycerin, however (see Clopton et al., 1991), these same oocysts appear dolioform and relatively smooth. Previous studies also suggest that gregarine oocysts are also notoriously uniform in size and shape, thus in principle, are good taxonomic characters (Clopton et al., 1991). The present work suggests that measurement conditions are of prime importance in assessing the differences between taxa in this regard.

Finally, although all the parasite species described and redescribed in this article are from the larval hosts, in culture, all of the adults are also infected with gregarine parasites that are generally indistinguishable from those in the larvae. Detwiler (2004) showed experimentally that gregarines from all the studied flour beetle species' larvae will infect their respective species' adults but was not able to do the reciprocal crosses because of logistical constraints. This work will be presented in detail in the near future, but, for the present, parasites described in the current article should probably be considered ones of both adults and larvae of their respective host species. In the case of holometabolic hosts, this question of cross-stadial infectivity is an important one because of the Clopton et al. (1992) demonstration of host stadium specificity in gregarine parasites of the confamilial Tenebrio molitor in contrast to the Watwood et al. (1997) experimental demonstration of both cross-stadial and cross-specific infectivity in Gregarina tribo- liorum from $T r$. confusum and Tr. castaneum. Tribolium madens, also obtained from the USDA Grain Marketing and Production Center in Manhattan, Kansas, at the same time as the other species used in the present study, has never been infected with any gregarines, either in the adult or larval stage, in this laboratory. Attempts to infect it with gregarines from other Tribolium species have not been successful, but those studies are still in a very preliminary stage. The varying degrees of host specificity among gregarines within this group of tenebrionid beetles thus adds to the value of the system as material to study the mechanisms by which host and parasite lineages develop over time.

\section{ACKNOWLEDGMENTS}

The authors are greatly indebted to Joe Siegel and Brenda Waters of the USDA Grain Marketing and Production Center in Manhattan, Kansas, for supplying us with cultures of Tribolium freemani, Tr. brevicornis, Tr. madens, and Palorus subdepressus. We also thank Kit Lee for his help with the scanning electron microscopy and Wendy Allen for her help with measurements and contribution of slides from $\mathrm{Tr}$. freemani.

\section{LITERATURE CITED}

Arnaud, L., H. T. T. Lan, Y. Brostaux, and E. Haubruge. 2005. Efficacy of diatomaceous earth formulations admixed with grain against populations of Tribolium castaneum. Journal of Stored Products Research 41: 121-130.

Belton, P., AND H. Grundfest. 1962. Potassium activation and K spikes in muscle fibers of mealworm larva (Tenebrio molitor). American Journal of Physiology 203: 588-594.

Caira, J. N., C. Richmond, AND J. Swanson. 2005. A revision of Phoreiobothrium (Tetraphyllidea: Onchobothriidae) with descriptions of five new species. Journal of Parasitology 91: 1153-1174.

Clopton, R. E. 1995. Leidyana migrator n. sp. (Apicomplexa: Eugregarinida: Leidyanidae) form the Madagascar hissing cockroach, Gromphadorhina portentosa (Insecta: Blattodea). Invertebrate Biology 114: 271-278.

. 1999. Revision of the genus Xiphocephalus and description of Xiphocephalus ellisi n. sp. (Apicomplexa: Eugregarinida: Stylocephalidae) from Eleodes opacus (Coleoptera: Tenebrionidae) in the western Nebraska sandhills. Journal of Parasitology 85: 84-89. . 2000. Order Eugregarinorida Léger, 1900. In The illustrated guide to the protozoa, 2nd ed., J. J. Lee, G. F. Leedale, and P. Bradbury (eds.). Society of Protozoologists, Lawrence, Kansas, p. 205-288.

. 2004a. Standard nomenclature and metrics of plane shapes for use in gregarine taxonomy. Comparative Parasitology 71: 130-140. . 2004b. Calyxocephalus karyopera g. nov., sp. nov. (Eugregarinorida: Actinocephalidae: Actinocephalinae) from the ebony jewelwing damselfly Calopteryx maculata (Zygoptera: Calopterygidae) in southeast Nebraska, U.S.A.: Implications for mechanical prey-vector stabilization of exogenous gregarine development. Comparative Parasitology 71: 141-153.

- , T. J. COOK, AND J. L. CoOK. 2004. Naiadocystis phykoterion $\mathrm{n}$. gen., n. sp. (Apicomplexa: Eugregarinida: Hirmocystidae), from the Mexican pygmy grasshopper, Paratettix mexicanus (Orthoptera: Tetrigidae), in the Texas Big Thicket with recognition of three previously described species of Naiadocystis. Journal of Parasitology 90: $301-307$.

—, AND J. JANOVY, JR. 1993. Developmental niche structure in the gregarine assemblage parasitizing Tenebrio molitor. Journal of Parasitology 79: 701-709.

- $\longrightarrow$ AND T. J. PERCIVAL. 1992. Host stadium specificity in the gregarine assemblage parasitizing Tenebrio molitor. Journal of Parasitology 78: 334-337.

, T. J. Percival, AND J. Janovy, JR. 1991. Gregarina niphandrodes n. sp. (Apicomplexa: Eugregarinorida) from adult Tenebrio molitor (L.) with oocyst descriptions of other gregarine parasites of the yellow mealworm. Journal of Protozoology 38: 472-479. 
Detwiler, J. T. 2004. Host specificity amongst gregarine species and their tenebrionid hosts from an experimental and phylogenetic perspective. M.S. Thesis, University of Nebraska-Lincoln, Lincoln, Nebraska, $82 \mathrm{p}$

Ghose, S., AND D. P. Haldar. 1989. Role of environmental factors in the incidence of two new species of apicomplexan parasites, Hirmocystis lophocateri sp. n. and Hirmocystis triboli sp. n. from coleopteran insects. Acta Protozoologica 28: 49-60.

- S. K. RAY, AND D. P. HALdAR. 1986. Neohirmocystidae fam. n., a new family of septate gregarines (Apicomplexa: Sporozoea) from insects. Acta Protozoologica 25: 453-464.

Good, N. E. 1936. The flour beetles of the genus Tribolium. USDA Technical Bulletin No. 468, Beltsville, Maryland, 58 p.

Gupta, S., AND D. P. HALdAR. 1987. Steinina palorusi n. sp., a new species of septate gregarines (Apicomplexa: Sporozoea) from the larva of a tenebrionid beetle. Archiv für Protistenkunde 133: 135 144.

IsHII, S. 1914. On four polycystid gregarines from the intestine of Tribolium ferrugineum F. Annotationes Zoologicae Japonenses 8: 435-441.

Kula, R. R., And R. E. Clopton. 1999. Amoebogregarina nigra n. gen., n. comb. (Apicomplexa: Gregarinidae) from adult Melanoplus differentialis (Orthoptera: Acrididae) in southeastern Nebraska. Journal of Parasitology 85: 321-325.

LEÓn-RÈGagnon, V., AND D. R. BROOKS. 2003. Molecular phylogeny of Haematoloechus Looss, 1899 (Digenea: Plagiorchidae), with emphasis on North American species. Journal of Parasitology 89: 1206-1211.
PAI, A., AND G. YAN. 2003. Effects of tapeworm infection on male reproductive success and mating vigor in the red flour beetle, Tribolium castaneum. Journal of Parasitology 89: 516-521.

Pritchard, M. H., AND G. O. W. KRUSE. 1982. The collection and preservation of animal parasites. University of Nebraska Press, Lincoln, Nebraska, 141 p.

SaHA, K., D. P. Haldar, And S. GHosh. 1995. Hirmocystis palorusii sp. n., a new species of septate gregarine from Palorus ratzeburgii (Coleoptera: Tenebrionidae). Acta Protozoologica 34: 221-226.

Sengupta, T., S. Ghosh, AND D. P. HAldar. 1991. The biology of Eliptocystis triboli n. gen., n. sp., infecting the larva of Tribolium castaneum (Herbst) in walnuts. Archiv für Protistenkunde 140: 209218.

Shostak, A. W., And K. A. Sмyth. 1998. Activity of flour beetles (Tribolium confusum) in the presence of feces from rats infected with rat tapeworm (Hymenolepis diminuta). Canadian Journal of Zoology 76: 1472-1479.

SNyder, S. D., AND V. V. TKaCH. 2001. Phylogenetic and biogeographical relationships among some holarctic frog lung flukes (Digenea: Haematoloechidae). Journal of Parasitology 87: 1433-1440.

Watwood, S., J. Janovy, JR., E. Peterson, And M. A. Addison. 1997. Gregarina triboliorum (Eugregarinida: Gregarinidae) n. sp. from Tribolium confusum, and resolution of the confused taxonomic history of Gregarina minuta Ishii 1914. Journal of Parasitology 83: 502-507.

Yan, G., S. Stevens, C. J. Goodnight, and J. Schall. 1998. Effects of a tapeworm parasite on the competition of Tribolium beetles. Ecology 79: 1093-1103. 